\title{
ESTIMATION OF STOCHASTIC FRONTIER COST EFFICIENCY FOR COMPANIES IN THE ELECTRICITY DISTRIBUTION SECTOR IN BRAZIL
}

\author{
Simone Caberte Naimer \\ João Serafim Tusi da Silveira \\ Lucas Veiga Ávila \\ Julio Cezar Mairesse Siluk
}

\begin{abstract}
This paper presents the estimation of a cost efficiency stochastic frontier panel for a sample of the Brazilian electricity distribution sector, using in the main function explanatory variables of average operational cost of the companies, such as average salary, cost of energy purchased and volume of energy supplied. In the equation of inefficiency is tested the average duration of the supply interruption per year in hours (DEC) and the average frequency of the supply interruption per year (FEC), as well as the productivity in MWhs sold by employee.
\end{abstract}

Key words: Technical Efficiency, Stochastic Frontier Cost Model, Econometric Analysis.

JEL classification: C4; C49.

\section{Introduction}

The application of econometric technique of stochastic frontier analysis of the efficiency of electricity distribution companies started gaining momentum in the mid-90s (Burns and Weyman, 1996). Since then, the international literature has seen an important development, but the most consistent applications are relatively recent .

Just over a decade, technicians of the World Bank (Estache et al., 2002) measured the efficiency Cia. South America, in a case study on international coordination of regulation of the power system. More recently, researchers at the CEPE - Centre for Energy Policy and Economics, Swiss Federal Institute of Technology, Zurich, Switzerland - triggered a succession of studies and research that culminated with a consolidated analysis of benchmarking applied to the distribution of electricity (Filippini et al., 2005 - with financial support from the Swiss Federal Office for Education and Science).

In Brazil, the econometric analysis of stochastic frontier efficiency in the electricity sector, is quite scarce. This paper seeks to contribute to the evolution of research in this area, replicating the methodology used by Tannuri - Pianto, Sousa and Arcoverde (2009).

\section{Specification of the econometric model}

Between theoretical and empirical references consulted is included Serrato (2007), who developed a survey at the University of Brasilia, to evaluate the use of parametric stochastic frontier method to quantify the cost efficiency of the transmission of energy. Such research has produced a number of pioneering and enlightening about the power transmission market in Brazil, especially as the cost efficiency of enterprises information.

The author in question shows that the parametric method for stochastic frontier can portray in quantitative values, the behavior of the transmission market in Brazil, with the use 
of this promising methodology to estimate the cost efficiency of enterprises, becoming a reliable tool in revision of tariffs.

The study collected data on the banks of ANEEL - Brazilian Electricity Regulatory Agency - and other sources, about the costs and technical information of the transmission companies operating in the market from January 1998 to August 2005. Among the explanatory variables are: average wage $\left(X_{1}\right)$, interest expense on line extension $\left(X_{2}\right)$, population density $\left(X_{3}\right)$, line extension $\left(X_{4}\right)$ and in function of inefficiency, the following factors: benefits for personnel cost $\left(Z_{1}\right)$, line extension of the company on total length of lines $\left(\mathrm{Z}_{2}\right)$ and catchment area $\left(\mathrm{Z}_{3}\right)$.

The transmission companies analyzed in this research were:

Empresa Amazonense de Transmissão de Energia; Empresa Paranaense de Transmissão de Energia; Empresa Regional de Transmissão de Energia; Inabensa Brasil LTDA; Empresa de Transmissão de Energia do Oeste; Expansion Transmissão de Energia Elétrica; Cachoeira Paulista Transmissora de Energia; Empresa Catarinense de Transmissão de Energia; Sul Transmissora de Energia; Transmissora Nordeste Sudeste; and Novatrans Energia.

We carried out estimations with the dependent variable in the form of total cost, according to the equations presented below:

$$
\begin{gathered}
\log C_{r}=\beta_{0}+\left(\beta_{1} \log X_{1}\right)+\beta_{2} X_{2}+\left(\beta_{3} \log X_{3}\right)+\beta_{i} X_{i}+v_{i}+u_{i} \\
m=\delta_{0}+\delta_{1} Z_{1}+\delta_{2} Z_{2}+\delta_{3} Z_{3}+\delta_{i} Z_{i}
\end{gathered}
$$

These equations are Cobb-Douglas functions, where the values of the $\beta$ 's represent the elasticities with respect to total cost. The equation of the second block, which depicts the effects of inefficiency is returned as the value of $m$ defined as the average of errors arising from the inefficiency.

Tannuri - Pianto, Arcoverde and Sousa (2009) also used the method of stochastic efficiency frontier to analyze 22 distribution companies in the Brazilian electric sector. Among the data analyzed by these researchers, are: operating cost, number of employees, volume of energy supplied, and some qualitative indicators such as the percentage of energy losses, the average duration of supply interruption per consumer per year in hours (DEC) and the average number of supply interruptions per consumer per year (FEC). They also considered some socioeconomic indicators. The information used to estimate production frontiers were drawn from the notebooks of the Infrastructure Economic Development Bank (BNDES), in the period 1993-2001. In summary, the research was based on the definition of the boundaries of production and cost estimation and its SFA (Stochastic Frontier Analysis).

Tannuri Pianto - and their partners consider the stochastic frontier model of cost efficiency with the following specification:

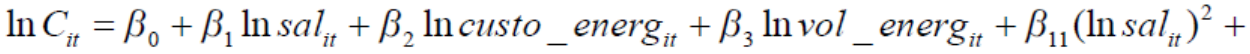

$$
\begin{aligned}
& \left.\left.\beta_{22}(\ln \text { custo_energ })_{i t}\right)^{2}+\beta_{33}(\ln v o l \text { energ })_{i t}\right)^{2}+\beta_{12} \ln \left(\text { sal }_{i t}\right) \ln (\text { custo_energ } i t)+ \\
& \beta_{13} \ln \left(\text { sal }_{i t}\right) \ln \left(\text { vol_energ }_{i t}\right)+\beta_{23} \ln \left(\text { custo_energ }_{i t}\right) \ln \left(\text { vol_energ }_{i t}\right)+\beta_{1 t} \ln \left(\text { sal }_{i t}\right) . t+ \\
& \beta_{2 t} \ln \left(\text { custo_energ } g_{i t}\right) \cdot t+\beta_{3 t} \ln \left(v_{\text {vol }} \text { energ } g_{i t}\right) \cdot t+\beta_{t} \cdot t+\beta_{t t} \cdot t^{2}+v_{i t}-u_{i t} \\
& \text { e } \\
& \mu_{i t}=\delta_{0}+\delta_{1} \text { mista }_{i t}+\delta_{2} \text { share }_{i t}+\delta_{3} \text { privat }_{i t}+\delta_{4} \text { denscon }
\end{aligned}
$$


Where $i$ indicates the observation of the $i$-th firm in the sample, $t$ indicates the $t$-th period; $C_{i t}$ is the average operating cost; $s a l_{i t}$ is the average wage; custo_energ $g_{i t}$ is the cost of purchased power; vol_energ ${ }_{i t}$ is the volume of energy supplied (in $\mathrm{MWH}$ ); denscon ${ }_{\text {it }}$ is the density of consumers and $v_{i t}$ are assumed to be iid variables with distribution $N\left(0, \sigma_{v}^{2}\right)$ independent of $u_{i t}$ 's. The $u_{i t}$ 's are non-negative techniques inefficiencies distributed independently such that $u_{i t}$ is obtained by truncating in zero of distribution $N\left(\mu_{i t}, \sigma_{u}^{2}\right)$, where the average is defined as an explicit function of specific variables vector Company, as specified.

In the present study, we used an adapted this model, where the average salary was calculated as the product of the cost of personnel and due to the volume of energy supplied by the number of employees, and the amount of energy supplied was calculated by adding the variable supply and distribution of energy. The values of the operating cost of the average wage and the cost of purchased power, were transformed into values in 2000, using as deflator the General Price Index - Internal Availability (IGP-DI) of Fundação Getúlio Vargas (FGV), extracted from the Journal Economic Environment (2002). In inefficiency function $u_{i t}$ were tested DEC, FEC and productivity variables.

Partial table with the data and its developments regarding translog function used are below, where 1, 2 and 3 represent the years 1998, 1999 and 2000, respectively, $y$ is the average operating cost, $\mathrm{x} 1$ is the average salary, $\mathrm{x} 2$ is the cost of purchased power, $\mathrm{x} 3$ is the volume of energy supplied; $\mathrm{z} 1$ is the DEC; $\mathrm{z} 2$ is the FEC, and $\mathrm{z} 3$ is productivity (PROD).

\begin{tabular}{|c|c|c|c|c|c|c|c|c|c|c|c|c|c|c|}
\hline Enterprise & Year & $\ln y$ & ln $\times 1$ & $\begin{array}{l}\text { ln } \\
\times 2\end{array}$ & ln $\times 3$ & $\begin{array}{l}(\ln \\
x 1)^{\wedge} 2\end{array}$ & $\begin{array}{c}(\ln \\
\times 2)^{\wedge} 2\end{array}$ & $\begin{array}{l}(\ln \\
\times 3)^{\wedge} 2\end{array}$ & $\begin{array}{l}\ln \times 1 \\
\cdot \ln \\
x 2\end{array}$ & $\begin{array}{c}\ln \times 1 \\
\cdot \ln \\
\times 3\end{array}$ & $\begin{array}{l}\ln \times 2 \\
\ln \times 3\end{array}$ & $\mathrm{z} 1=\mathrm{DEC}$ & $\mathrm{z} 2=\mathrm{FEC}$ & $\mathrm{z} 3=\mathrm{PROD}$ \\
\hline 1 & 1 & 4,54 & 10,39 & 4,07 & 15,66 & 107,94 & 16,57 & 245,37 & 42,29 & 162,74 & 63,77 & 17,53 & 19,98 & 6780 \\
\hline 2 & 1 & 4,69 & 11,21 & 3,92 & 15,05 & 125,77 & 15,34 & 226,60 & 43,92 & 168,82 & 58,95 & 17,7 & 21,09 & 2468 \\
\hline 3 & 1 & 4,60 & 10,91 & 3,90 & 16,20 & 119,10 & 15,19 & 262,31 & 42,54 & 176,75 & 63,13 & 30,86 & 19,1 & 2407 \\
\hline 1 & 2 & 4,49 & 11,38 & 3,95 & 15,74 & 129,61 & 15,63 & 247,70 & $45,0 \odot$ & 179,18 & 62,22 & 18,26 & 17,11 & 9529 \\
\hline 2 & 2 & 4,68 & 11,08 & 3,92 & 15,10 & 122,81 & 15,33 & 228,12 & 43,40 & 167,38 & 59,14 & 15,2 & 16,48 & 2708 \\
\hline 3 & 2 & 4,52 & 10,87 & 3,95 & 16,25 & 118,09 & 15,59 & 263,93 & 42,91 & 176,54 & 64,15 & 25,38 & 17,09 & 2498 \\
\hline 1 & 3 & 4,40 & 10,59 & 4,02 & 15,82 & 112,20 & 16,15 & 250,13 & 42,57 & 167,53 & 63,56 & 24,46 & 18,6 & 9330 \\
\hline 2 & 3 & 4,63 & 11,10 & 3,85 & 15,18 & 123,19 & 14,80 & 230,50 & 42,70 & 168,51 & 58,41 & 14,4 & 14,35 & 2988 \\
\hline 3 & 3 & 4,48 & 10,76 & 3,96 & 16,32 & 115,70 & 15,68 & 266,25 & 42,59 & 175,51 & 64,61 & 21,95 & 17,9 & 2709 \\
\hline
\end{tabular}

\section{Application}

The process carried out with the Frontier software version 4.1 (Coelli, 1996), after several iterations involving different combinations of variables, converged to the best result, which is shown below.

\begin{tabular}{|c|c|c|c|}
\hline & coefficient & standard-error & t-ratio \\
\hline beta $\odot$ & $\odot .64587603 \mathrm{E}+02$ & $\odot .64624683 E+01$ & $\odot .99942623 \mathrm{E}+01$ \\
\hline beta 1 & $-\odot .57994181 E+01$ & $\odot .84613477 \mathrm{E}+\odot \odot$ & $-\odot .68540123 E+01$ \\
\hline beta 2 & $-\odot .71199227 E+01$ & $\odot .12400963 E+01$ & $-\odot .57414273 E+01$ \\
\hline beta 3 & $-0.20833610 E+01$ & $\odot .48784714 \mathrm{E}+\odot \odot$ & $-0.42705201 \mathrm{E}+01$ \\
\hline beta 4 & $\odot .27122791 \mathrm{E}+\odot \odot$ & $\odot .33333859 \mathrm{E}-01$ & $\odot .81367091 \mathrm{E}+01$ \\
\hline beta 5 & $\odot .50933801 E+\odot \odot$ & $\odot .13532011 \mathrm{E}+\odot \odot$ & $\odot .37639492 \mathrm{E}+\odot 1$ \\
\hline delta $\odot$ & $0.51554016 \mathrm{E}+00$ & $\odot .15394315 \mathrm{E}+00$ & $0.33488996 \mathrm{E}+01$ \\
\hline delta 1 & $-0.54597682 \mathrm{E}-02$ & $\odot .32130295 E-02$ & $-0.16992586 E+01$ \\
\hline delta 2 & $0.53390517 \mathrm{E}-02$ & $\odot .26179133 \mathrm{E}-02$ & $0.20394303 \mathrm{E}+01$ \\
\hline delta 3 & $-\odot .87960621 E-\odot 4$ & $\odot .47373376 \mathrm{E}-\odot 4$ & $-\odot .18567522 E+01$ \\
\hline sigma-squared & $\odot .44447727 \mathrm{E}-02$ & $\odot .94988078 \mathrm{E}-\odot 3$ & $\odot .46792953 \mathrm{E}+01$ \\
\hline gamma & $\odot .98432517 \mathrm{E}+\odot \odot$ & $\odot .27986126 \mathrm{E}+\odot \odot$ & $\odot .35171899 \mathrm{E}+\odot 1$ \\
\hline
\end{tabular}


The equations constructed with the estimated coefficients above are:

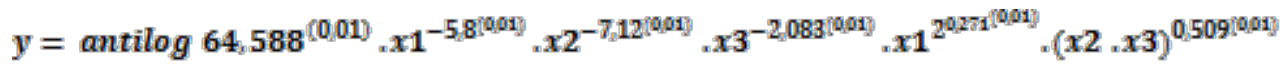

and

$U_{i}=0,515^{(0,01)}-0,00546^{(0,05)} \cdot D E C+0,00534^{(0,01)}$. FEC $-0,000088^{(0,05)} \cdot$ PROD

with total residual variance range and equal respectively to

$\sigma^{2}=0,00444^{(0,01)} ;$ e $\quad \gamma=0,984^{(0,01)}$

where the numbers in parentheses are the corresponding levels of the Student's t distribution significance.

It is noted that the main operating cost of equation $(y)$ all coefficients are statistically significant at $1 \%$.

In inefficiency equation $(U i)$, the coefficients are statistically significant at $1 \%$, with the exception of accompanying DEC and PROD variables, whose statistical significance is also quite acceptable, the level of $5 \%$.

The statistical significance of the overall residual variance and range (sealer degree of stochasticity) are excellent - both at levels of $1 \%$.

Finally, it is noted that all signs of the coefficients are in agreement with expectations.

In turn, the efficiency indices for each distribution in each year studied, are as follows:

\begin{tabular}{|c|c|c|}
\hline DISTRIBUTORS & YEAR & SCORE \\
\hline AES & 1998 & $1, \odot 7 E+\odot \odot$ \\
\hline CEB & 1998 & $1,28 \mathrm{E}+\Theta \Theta$ \\
\hline CELESC & 1998 & $1,41 \mathrm{E}+00$ \\
\hline CELG & 1998 & $1,45 \mathrm{E}+0 \odot$ \\
\hline CELPE & 1998 & $1,23 \mathrm{E}+0 \odot$ \\
\hline CEMAT & 1998 & $1,55 \mathrm{E}+00$ \\
\hline CERJ & 1998 & $1, \odot 6 \mathrm{E}+\odot \odot$ \\
\hline ENERSUL & 1998 & $1,28 \mathrm{E}+\odot \odot$ \\
\hline ESCELSA & 1998 & $1,12 \mathrm{E}+0 \odot$ \\
\hline LIGHT & 1998 & $1,30 E+\odot \odot$ \\
\hline RGE & 1998 & $1,18 \mathrm{E}+\odot \odot$ \\
\hline AES & 1999 & $1,01 \mathrm{E}+\odot \odot$ \\
\hline CEB & 1999 & $1,32 \mathrm{E}+0 \odot$ \\
\hline CELESC & 1999 & $1,23 \mathrm{E}+\odot \odot$ \\
\hline CELG & 1999 & $1,29 \mathrm{E}+0 \odot$ \\
\hline CELPE & 1999 & $1,24 \mathrm{E}+\odot \odot$ \\
\hline CEMAT & 1999 & $1,59 \mathrm{E}+\odot \odot$ \\
\hline CERJ & 1999 & $1,14 \mathrm{E}+\odot \odot$ \\
\hline ENERSUL & 1999 & $1,4 \odot E+\odot \odot$ \\
\hline ESCELSA & 1999 & $1,19 \mathrm{E}+\odot \odot$ \\
\hline LIGHT & 1999 & $1,12 \mathrm{E}+\odot \odot$ \\
\hline RGE & 1999 & $1,17 \mathrm{E}+\odot \odot$ \\
\hline AES & 2000 & $1,01 \mathrm{E}+\odot \odot$ \\
\hline CEB & 2000 & $1,32 \mathrm{E}+\odot \odot$ \\
\hline CELESC & 2000 & $1,19 \mathrm{E}+00$ \\
\hline CELG & 2000 & $1,46 \mathrm{E}+\odot \odot$ \\
\hline
\end{tabular}




\begin{tabular}{lcc}
\multicolumn{1}{c}{ DISTRIBUTORS } & YEAR & SCORE \\
CELPE & $200 \odot$ & $1,40 \mathrm{E}+\odot \odot$ \\
CEMAT & $200 \odot$ & $1,61 \mathrm{E}+\odot \odot$ \\
CERJ & $200 \odot$ & $1,22 \mathrm{E}+\odot \odot$ \\
ENERSUL & $200 \odot$ & $1,33 \mathrm{E}+\odot \odot$ \\
ESCELSA & $200 \odot$ & $1,01 \mathrm{E}+\odot \odot$ \\
LIGHT & $200 \odot$ & $1,13 \mathrm{E}+\odot \odot$ \\
RGE & $200 \odot$ & $1,28 \mathrm{E}+\odot \odot$
\end{tabular}

\section{Conclusion}

Among the main results shown by analysis of ships in the research model, it appears that the variations of the average wage, the cost of purchased power, the volume of energy supplied and the product of these two variables explain a high degree of significance changes occurred in the middle operating costs of the distributors sampled in the years of 1998, 1999 and 2000.

Regarding the inefficiency equation, it is observed that the evolution of DEC has caused lowering effects in the indices of technical efficiency of the operating cost. Already, the effects of DEC and productivity were beneficial for improving the degree of technical efficiency of the operating cost.

For purposes of measures and actions aimed at improving cost efficiency, distributors must primarily target these variables and use the estimated indices (listed at the end of the previous section) to effect comparisons with the performance of others.

\section{References}

Burns, P. and T. Weyman-Jones (1996) "Cost Functions and Cost Efficiency in Electricity Distribution: A Stochastic Frontier Approach.” Bulletin of Economic Research 48.

Coelli, Tim (1996) "A Guide to FRONTIER Version 4.1: A Computer Program for Stochastic Frontier Production and Cost Function Estimation", CEPA Working Paper 96/07, Department of Econometrics, University of New England, Armidale.

Estache, A.. and M. A. Rossi and C. A. Ruzzier (2002) "The Case for International Coordination of Electricity Regulation: Evidence from the Measurement of Efficiency in South America", World Bank Policy Research Working Paper 2907, October.

Filippini, M. and Farsi, M. and Fetz, A. (2005) "Benchmarking Analysis in Electricity Distribution”, Working Paper 39, Centre for Energy Policy and Economics, Swiss Federal Institute of Technology, Zurich, Switzerland.

Serrato, E. (2007) "Eficiência de custo das transmissoras de energia elétrica do Brasil: uma abordagem paramétrica por fronteira estocástica”. In: Congresso Brasileiro de Regulação, 5, Recife, Brazil.

Tannuri-Pianto, Sousa and Arcoverde (2009) "Fronteiras de Eficiência Estocásticas para as Empresas de Distribuição de Energia Elétrica no Brasil: Uma Análise de Dados de Painel”, Estudos Econômicos, São Paulo, Brazil, v. 39, n. 1, p.221-247. 